\title{
EVAUATION OF SANITARY HYGIENIC PRACTICES IN THE PRODUCTION OF AÇAÍ IN THE BOWL: DIAGNOSIS AND INTERVENTION
}

\author{
AVALIAÇÃO DAS PRÁTICAS HIGIÊNICO SANITÁRIAS NA PRODUÇÃO DE AÇAÍ NA TIGELA: \\ DIAGNÓSTICO E INTERVENÇÃO \\ EVALUACIÓN DE PRÁCTICAS HIGIÉNICAS SANITARIAS EN LA PRODUCCIÓN DE \\ AÇAÍ EN TIGELA: DIAGNÓSTICO E INTERVENCIÓN
}

\section{Eveline Gomes Rosa de Moura $^{1}$, Thaynara Cristina de Oliveira ${ }^{1}$, Daniela Ayumi} Amemiya $^{1}$, Carolina Fernandes Nobre ${ }^{1}$, Raquel Troncoso Chaves Moreno ${ }^{1}$, Maria Raquel Hidalgo Campos ${ }^{1}$, Liana Jayme Borges ${ }^{1}$, Maria Cláudia Dantas Porfírio Borges André ${ }^{1}$, Tatianne Ferreira de Oliveira ${ }^{2 *}$

${ }^{1}$ Laboratory of Food Hygienic-Sanitary Control, Faculty of Nutrition, Federal University of Goiás. Street 227, East University district, Goiânia, Goiás, Brazil.

${ }^{2}$ School of Agronomy, Federal University of Goiás - UFG, Samambaia Campus, Goiânia, Goiás, Brazil.

*Corresponding author.ferreira.tatianne@yahoo.com.br

\section{ABSTRACT}

The aim of this work was to evaluate the nutritional and microbiological quality of ready-to-eat açai, the physical and functional conditions of establishments that market this product and to verify the presence of microorganisms at handlers' hands and nostrils. Twenty-three establishments in the city of Goiânia-Goiás were evaluated and açaí samples were obtained in two steps: before and after the training of handlers about good manufacturing practices. A decrease in the counts of total coliforms (from $26.08 \%$ to $8.7 \%$ of samples), coagulase positive staphylococci (from $78.26 \%$ to $65.2 \%$ of samples) and aerobic mesophiles (from $100 \%$ to $73.91 \%$ of samples) was observed between steps. The presence of microorganisms at handlers' hands and nostrils did not present statistical difference between the two steps. According to the applied checklist, six items showed reduced compliance. After the training of handlers, the microbiological contamination of açaí decreased, and the presence of $E$ coli in handlers' nostrils was no longer observed, which highlights the importance of training about the implementation Good Manufacturing Practices to ensure food sanitary quality.

Keywords: checklist, acai, intervention

\section{RESUMO}

O objetivo deste trabalho foi avaliar a qualidade nutricional e microbiológica do açaí pronto para consumo, as condições físicas e funcionais dos estabelecimentos que comercializam esse produto e verificar a presença de microrganismos nas mãos e nas narinas dos manipuladores. Foram avaliados 23 estabelecimentos da cidade de Goiânia-Goiás e as amostras de açaí foram obtidas em duas etapas: antes e após o treinamento dos manipuladores sobre as boas práticas de fabricação. Observou-se uma diminuição nas contagens de coliformes totais (de 26,08\% para 8,7\% das amostras), estafilococos positivos para coagulase (de 78,26\% para 65,2\% das amostras) e mesófilos aeróbicos (de 100\% para 73,91\% das amostras). A presença de microrganismos nas mãos e nas narinas dos manipuladores não apresentou diferença estatística entre as duas etapas. De acordo com a lista de verificação aplicada, seis itens apresentaram conformidade reduzida. Após o treinamento dos manipuladores, a contaminação microbiológica do açaí diminuiu e a presença de E. coli nas narinas dos manipuladores não foi mais observada, o 
que destaca a importância do treinamento sobre a implementação de Boas Práticas de Fabricação para garantir a qualidade sanitária dos alimentos.

Palavras-chave: checklist, açaí, intervenção

\section{RESUMEM}

El objetivo de este trabajo fue evaluar la calidad nutricional y microbiológica del açai listo para comer, las condiciones físicas y funcionales de los establecimientos que comercializan este producto y verificar la presencia de microorganismos en las manos y fosas nasales de los manipuladores. Se evaluaron 23 establecimientos en la ciudad de Goiânia - Goiás y se obtuvieron muestras de açaí en dos pasos: antes y después de la capacitación de los manipuladores sobre las buenas prácticas de fabricación. Se observó una disminución en los recuentos de coliformes totales (del 26.08\% al $8.7 \%$ de las muestras), estafilococos coagulasa positivos (del $78.26 \%$ al $65.2 \%$ de las muestras) y mesófilos aeróbicos (del $100 \%$ al $73.91 \%$ de las muestras) entre los pasos. La presencia de microorganismos en las manos y fosas nasales de los manipuladores no presentó diferencias estadísticas entre los dos pasos. Según la lista de verificación aplicada, seis ítems mostraron un cumplimiento reducido. Después de la capacitación de los manipuladores, la contaminación microbiológica del açaí disminuyó y ya no se observó la presencia de E. coli en las fosas nasales de los manipuladores, lo que resalta la importancia de la capacitación sobre la implementación de Buenas Prácticas de Manufactura para garantizar la calidad sanitaria de los alimentos.

Descriptores: lista de verificación, acai, intervención

\section{INTRODUCTION}

Açaí (Euterpe oleracea Martius) is a tree palm native to the Amazon region that plays an important socio-economic role in the region, and its fruit is traditionally consumed by the population of northern Brazil. With market growth, açai also has been marketed and consumed in other regions of the country, and also being exported to other regions such as United States, Japan, China and Europe (COSTA et al., 2015; PORTINHO et al., 2012).

Açaí has several beneficial health effects such as anti-inflammatory, antioxidant and immunomodulating properties, hypocholesterolemic effect, cardioprotective activities and reduced risk of coronary heart disease. The effects are associated with its chemical composition, especially the presence of bioactive substances, such as phenolics, flavonoids and anthocyanins (YAMAGUCHI et al., 2015; PERINI et al., 2018).

Wine or pulp are extracted from açai, which have several culinary applications, being marketed as frozen pulp ready for consumption added of fruits, guarana syrup and granola. Açai fruits are highly perishable and can present high bioburden, due to inadequate collection, conditioning, transport, processing and handling conditions (EMBRAPA, 2013).

The sanitary hygienic quality of foods is subject to Good Practices in Food Services, adopting the use of a checklist to diagnose how these criteria are being met (FARIA et al., 2012).

When a meal producing establishment does not promote proper deployment and implementation of Good Manufacturing Practices, the contamination of food produced is very likely to occur during handling, distribution and storage processes, which can lead to outbreaks of foodborne diseases (SANI and SION, 2014; SACCOL et al, 2015).

With the increasing commercialization and consumption of açai, the present study aims to assess the nutritional and microbiological quality of açai fruit pulp, as well as the physical and functional conditions of establishments that market this product and to verify the presence of microorganisms at handlers' hands and 
nostrils before and after their training in Good Practices.

\section{MATERIAL AND METHODS}

In the metropolitan area of Goiânia, Goiás, 23 establishments that marketed açai prepared with guarana syrup were selected, one added of strawberry and another added of banana. Thirty-four handlers were also surveyed. Two samples $(300 \mathrm{ml})$ of the product, one with banana and the other with strawberry were aseptically collected from each açai selling establishment, totaling 46 samples. Samples were transported to laboratory under $5^{\circ} \mathrm{C}$ controlled temperature in a maximum of one hour period.

\subsection{Microbiological analysis of açaí}

Microbiological protocol includes coliform counts at $35^{\circ}$ and $45^{\circ} \mathrm{C}$, coagulase-positive staphylococci, mesophilic aerobic bactéria, Bacilus cereus and E. coli and Salmonella sp research according to methodology proposed by APHA (2001).

\subsection{Microbiological analysis of hand and nostril} surfaces

Samples from handlers' hands and nostrils were collected using a swab previously moistened in saline solution. After collection, the swab was immersed in tube containing brain heart infusion broth (BHI) and then transported to the laboratory, under $5^{\circ}$ $\mathrm{C}$ controlled temperature in a maximum of one hour period. For these samples, Escherichia coli and Staphylococcus aureus were analyzed according to methodology proposed by APHA (2001).

\subsection{Training in Good Manufacturing Practices}

The training of handlers occurred in each researched establishment and lasted about one hour.
The content covered was based on the Handbook on Good Practices for Food Services /ANVISA (BRASIL, 2004).

Before training, a pretest was applied to evaluate the previous knowledge of handlers about the subject. After intervention, a post-test was applied with the same questions as the pretest to verify content assimilation.

\subsection{Diagnosis of physical and functional conditions}

To evaluate the physical and functional conditions of establishments, a checklist based on Resolution RDC n 216/2004 was used, which was provided by the Health Surveillance of the city of Goiânia (BRASIL, 2004).

\subsection{Chemical composition determination}

The analyses performed included contents of lipids, crude protein, moisture, ashes and carbohydrates, according to methodology proposed by AOAC (2012). All analyses were performed in triplicate.

\subsection{Statistical analysis}

The chi-square test $\left(\chi^{2}\right)$ for microbiological analyses and surfaces of hands and nasal cavities was applied. For aerobic bacteria, t-Student test was applied, and to compare the results before and after training in good practices, the Fisher exact test was used. Mann-Whitney test was used for nutritional assessment, adopting significance level of $5 \%(p<0.05)$ for all analyses. Data analysis was performed using the StatSoft Inc., 2005. STATISTICA software (Data Analysis Software System), version 7.1. 


\subsection{Ethical aspects}

The project was approved by the Ethics Research Committee of the Federal University of Goiás under protocol number 039/2012.

\section{RESULTS AND DISCUSSION}

\subsection{Microbiological contamination of açaí}

The results of microbiological analyses are shown in Table 1, which did not detect the presence of E. coli, B. cereus and Salmonella spp. in none of the 46 açaí samples analyzed, before and after the training of handlers on good food practices.

According to Table 1, $78.26 \%$ of samples initially analyzed were contaminated by coagulasepositive staphylococci. According to Fijalkowski et al (2016), Staphylococci present in the human microbiota are not naturally found in fresh food, and contamination usually occurs through handlers. Faria et al (2012) analyzed 36 açaí pulp samples and found that $75 \%$ of them were in disagreement with current microbiological standards, which confirmed the presence of coliforms in $16.7 \%$ and E. coli in $13.8 \%$ of the 27 samples contaminated by total coliforms.

The presence of fecal coliforms, especially $E$. coli, indicates probable fecal origin contamination, whether human or animal, of food or water used in the establishment, being this contamination suggestive of inadequate hygiene practices during food handling and during the production chain processes (MORRIS et al, 2016; SANGADKIT et al, 2012).
The results of Table 1 also indicate that training in Good Food Manufacturing Practices can contribute to improve the hygienic-sanitary conditions by significantly reducing the counts of Coagulase positive staphylococci, mesophilic aerobic bacteria and total coliforms after this process, although this reduction did not occur for coliform at $45^{\circ} \mathrm{C}$ counts. Similar results were found by Soares et al (2013), who analyzed samples of surfaces of utensils and production area equipments and also observed reduction of the microbiological counts for molds, yeasts and total plate count after the training of handlers in Good Food Manufacturing Practices.

In the present study, there was a significant variation in the mesophilic aerobic bacteria counts, which reached levels that made their numbering unfeasible. Similar results were found by Faria et al (2012) in açaí pulps. Although Brazilian sanitary legislation does not establish microbiological standards for these bacteria in ready-to-eat açai, their analysis is important as a strategy of hygienic-sanitary control, since they are related with sanitary food quality (YUYAMA et al., 2011).

Table 1. Microbiological analysis of açaí before and after the training of handlers on good food practices. Goiânia, Goiás.

\begin{tabular}{|c|c|c|c|c|c|}
\hline \multirow{3}{*}{ Microorganisms } & \multicolumn{4}{|c|}{ STEPS } & \multirow{3}{*}{$p *$ value } \\
\hline & \multicolumn{2}{|c|}{ Before } & \multicolumn{2}{|c|}{ After } & \\
\hline & n $(\%)$ & $\begin{array}{c}\text { Score } \\
\text { (UFC/mL) }\end{array}$ & n $(\%)$ & Score $(\mathrm{UFC} / \mathrm{m}]$ & \\
\hline
\end{tabular}




\begin{tabular}{|c|c|c|c|c|c|}
\hline Total coliforms & $\begin{array}{c}12 \\
(26.08)\end{array}$ & - & $4(8.7)$ & - & $0.02^{\mathrm{a}}$ \\
\hline $\begin{array}{l}\text { Coliforms at } 45 \\
{ }^{\circ} \mathrm{C} / \mathrm{g}\end{array}$ & $7(15.21)$ & $\begin{array}{l}1.0 \times 10 \text { to } \\
4.2 \times 10^{3}\end{array}$ & $\begin{array}{c}10 \\
(21.73)\end{array}$ & $\begin{array}{l}1.1 \times 10 \text { to } \\
1.56 \times 10^{4}\end{array}$ & $0.36^{\mathrm{a}}$ \\
\hline $\begin{array}{l}\text { Coagulase-positive } \\
\text { Staphylococci }\end{array}$ & $\begin{array}{c}36 \\
(78.26)\end{array}$ & $\begin{array}{l}4.4 \times 10^{2} \text { to } \\
3.64 \times 10^{5}\end{array}$ & $3(6.52)$ & $\begin{array}{c}1.0 \times 10^{3} \text { to } \\
3.0 \times 10^{3}\end{array}$ & $0.00^{\mathrm{a}}$ \\
\hline $\begin{array}{l}\text { Mesophilic aerobic } \\
\text { bacteria }\end{array}$ & $46(100)$ & $\begin{array}{l}2.0 \times 10 \text { to } \\
\text { "uncountable" }\end{array}$ & $\begin{array}{c}34 \\
(73.91)\end{array}$ & $\begin{array}{c}9.0 \times 10^{2} \text { to } \\
3.9 \times 10^{4}\end{array}$ & $0.00^{\mathrm{b}}$ \\
\hline
\end{tabular}

Table 2. Presence of Escherichia coli and Staphylococcus aureus in açaí handlers' hands and nostrils. Goiânia,

\begin{tabular}{|c|c|c|c|c|c|c|c|c|c|c|}
\hline \multirow{4}{*}{ Microorganism } & \multicolumn{10}{|c|}{ Anatomical area } \\
\hline & \multicolumn{5}{|c|}{ Hands } & \multicolumn{5}{|c|}{ Nostrils } \\
\hline & \multicolumn{2}{|c|}{ Before } & \multicolumn{2}{|c|}{ After } & \multirow[t]{2}{*}{$p^{*}$} & \multicolumn{2}{|c|}{ Before } & \multicolumn{2}{|c|}{ After } & \multirow[t]{2}{*}{$p^{*}$} \\
\hline & $\mathrm{n}$ & $\%$ & $\mathrm{n}$ & $\%$ & & $\mathrm{n}$ & $\%$ & $\mathrm{n}$ & $\%$ & \\
\hline E. coli & 1 & 2.94 & 1 & 2.94 & 0.61 & 5 & 14.70 & 0 & 0 & 0.1 \\
\hline S. aureus & 1 & 2.94 & 3 & 8.82 & 0.61 & 5 & 14.70 & 7 & 20.58 & 0.18 \\
\hline
\end{tabular}

* Chi-square test $\left(\chi^{2}\right)$

\subsection{Contamination in handlers' hands and nostrils}

There was no statistical difference regarding the presence of $E$. coli and $S$. aureus between steps in handlers' hands and nostrils (Table 2).

In this study, 34 handlers were analyzed and although without statistical significance ( $p>0.05)$, the presence of $E$. coli in handlers' nostrils was completely reduced after training. However, the presence of $S$. aureus increased both in their hands and nostrils after training (Tabela 2). This possibly occurred due to the lack of interest from some handlers to participate in the training, in addition to inadequate personal hygiene practices, such as incorrect hand hygiene and also to the lack of appropriate material available for antisepsis. Similar results were found by Sores et al (2012) in schools in the city of Camaçari, Brazil, in which $97.8 \%$ of surveyed handlers had already undergone training about good practices in food production and the presence of Coagulase positive staphylococci was detected in the hands of $53.3 \%$ of handlers.
Nasrolahei et al (2016) evaluated the fingernails of 220 food handlers from different market segments and found the presence of Staphylococcus aureus in 46\% and Escherichia coli in $29 \%$ of surveyed participants, also identifying the presence of Staphylococcus aureus $n$ the nostrils of $65 \%$ of handlers

\subsection{Training in Good Food Practices}

Regarding the tests applied before and after training, no statistical significance was observed when they were compared. The mean pre-test accuracy was $86.8 \%$ and post-test accuracy was $97 \%$, and the most frequent errors were related to "necessary conditions for the multiplication of microorganisms", "food handler concept", "correct hygiene of vegetables and fruits" and "concept of foodborne disease".

In a study carried out by Kunadu et al (2016), regarding the pre-test applied during training, it was observed that most handlers had no knowledge that microorganism can cause foodborne disease through the contamination of raw materials, ready-to-eat foods, 
surfaces and utensils. The knowledge about food contamination is important for preventing crosscontamination during handling and storage (KUNADU et al., 2016).

Rebouças et al (2016) conducted a study with 265 handlers working in hotel kitchens in the city Salvador, Brazil, and identified that $17 \%$ of them had never participated of training on good food manufacturing practices, and $44 \%$ of them had not undergone training in the last six months.

In the study of Rebouças et al (2016), although most handlers have informed in questionnaire knowledge about adequate hygienic sanitary practices, checklist results have shown that most of them did not follow the suggested hand hygiene frequency.
When comparing the training of handlers about hygienic-sanitary conditions of restaurants, Mello et al (2010) observed a weak positive correlation, indicating that, despite the importance of training, other factors may influence these conditions such as inappropriate physical structure, lack of equipment and maintenance of utensils, in addition to the high labor turnover.

\subsection{Physical and functional conditions of establishments}

Of the 12 items assessed in the checklist, three improved the compliance level from one step to the other and six items reduced the compliance level after training, with significant value $(p=0.01)$ only for “food preparation" block (Figure 1).

Figure 1. Conformity of assessed checklist items based on RDC $n^{\circ} 216 / A N V I S A$, before and after training on good food practices. Goiânia, Goiás.

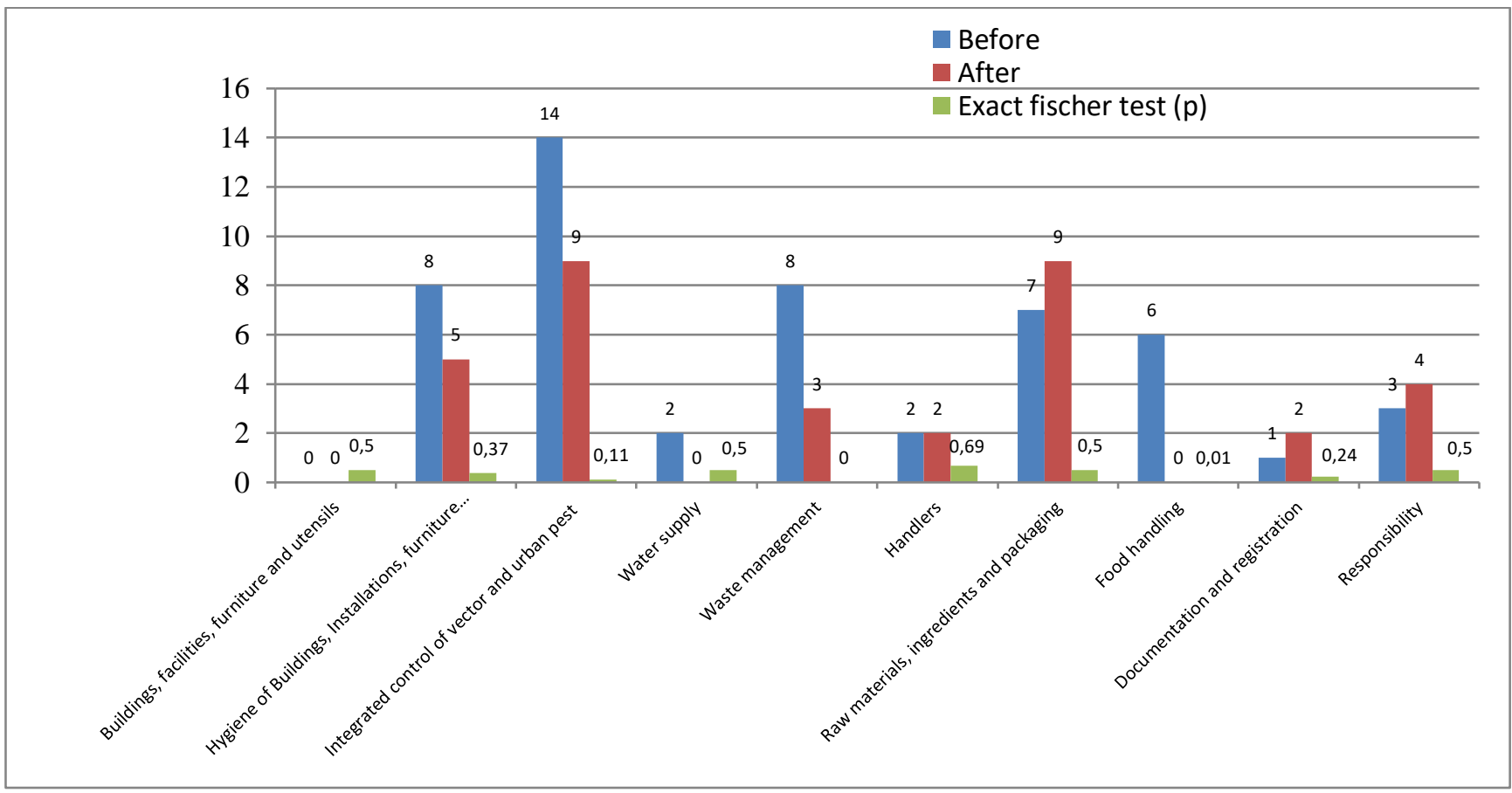

Some of the major flaws detected that may favor food contamination were: absence of a trained person for sanitizing functions, absence of frequency control for facility hygiene, use of cleaning products unregulated by the Ministry of Health and storage in inappropriate places.

The surveyed establishments also presented visually precarious situations in relation to environment and food hygiene, and practices of handlers involved in the production process. Saccol et 
al (2013) studied self-service restaurants in the city of São Paulo, Brazil, and also found high levels of nonconformity related to inadequate hygiene habits, lack of uniforms and inefficient hand hygiene.

A study carried out by Rebouças et al (2016) reported that improper handling practices such as inadequate temperature during production and storage, cross- contamination and insufficient personal hygiene, are responsible for most cases of foodborn diseases.

The visit in some places showed the presence of vectors and pests in the production area, and some establishments did not present updated records about Integrated Pest Management. In a study carried out by Saccol et al (2013), high compliance rates with legislation were found in relation to Integrated Pest Management. Similar fact was observed with respect to the water reservoir. Although water supply is from the public network, most establishment owners did not comply with periodic hygiene of water reservoir, unaware of its conservation status and, consequently, the water quality used in açaí processing.

Regarding item "exposure to the consumption of prepared food", the percentage of adequacy found in the study was low, representing a risk to consumer's health. The most important critical points were: no antisepsis of hands before preparing açaí, lack of temperature monitoring and lack of equipment maintenance control for product displays; storage of non-disposable consumables in unprotected sites, close to cleaning products.

Most surveyed establishments do not have the Handbook of Good Practices (MBP) and Standard Operating Procedures (POP), documents required by the sanitary legislation in force in Brazil.

Most of the food-producing establishments find difficulties to develop and implement good manufacturing practices, mainly related to: lack of resources, precarious physical structure, low schooling levels of handlers, high production volume, lack of employee motivation and inadequate equipment (SAORES et al., 2012; SACCOL et al, 2015).

\subsection{Nutritional quality of açaí}

Regarding the centesimal composition (Table 3 ), the product presented nearly $110 \mathrm{Kcal} / 100 \mathrm{~g}$. There was no statistical difference for parameters analyzed between the two types of açai (added of banana and strawberry), except for the moisture content, in which the strawberry product presented higher values $(91.5 \%)$ in relation to açai added of banana $(71.9 \%)$ $(p<0.05)$.

Table 3. Centesimal composition of açaí added of banana and strawberry marketed in Goiânia

SD: standard deviation

\begin{tabular}{lccc}
\hline $\begin{array}{c}\text { Parameters } \\
\text { analyzed }\end{array}$ & $\begin{array}{c}\text { Açai with } \\
\text { banana } \\
\text { average } \pm \text { SD) }\end{array}$ & $\begin{array}{c}\text { Açaí with } \\
\text { strawberry } \\
\text { average } \pm \text { SD) }\end{array}$ & $\begin{array}{c}\boldsymbol{p} \\
\text { value }\end{array}$ \\
\hline Energetic & 111.67 & 109.83 & - \\
value (Kcal) & $73.42 \pm 0.47$ & $78.65 \pm 0.26$ & 0.00 \\
Moisture (g) & $8.88 \pm 0.25$ & $8.60 \pm 0.40$ & 0.19 \\
Proteins (g) & $3.07 \pm 0.10$ & $2.71 \pm 0.08$ & 0.76 \\
Lipids (g) & $12.13 \pm 0.26$ & $12.76 \pm 0.74$ & 0.06 \\
Carbohydrates & & & \\
(g) & $0.35 \pm 0.01$ & $0.34 \pm 0.04$ & 0.39 \\
Ashes (g) & & & \\
\hline
\end{tabular}

The energy content verified in the product is similar to that found in studies with açaí and its derivatives (Fregonesi et al., 2010; Yuyama et al., 2011).

Açaí has relatively low carbohydrate content; however, due to the addition of guarana and fruit syrup, higher macronutrient content was obtained in the samples analyzed. According to Fregonesi et al (2010), the results presented large fluctuations in values, which may be due to variations in the amount of water used in the extraction process, to the maturation stage of fruits used in the production of frozen pulp and/or the harvesting time of fruits (Fregonesi et al., 2010). 
The ash content expresses the content of inorganic substances (minerals) present in açai. Fregonesi et al., (2010) also did not find statistically significant difference in the ash content among three different types of frozen açaí pulp.

Variations in the concentrations of açaí nutritional constituents may be due to factors related to the fruit such as development of mechanisms of morphological and anatomical adaptation of different species, according to the environmental characteristics of each ecosystem (YUYAMA et al., 2011).

During this study, it was also observed that handlers do not follow a pre-established criteria in relation to the portioning of ingredients based on subjectivity and/or personal taste, which may modify the nutritional content of the final product due to the lack of recipe standardization.

\section{CONCLUSION}

After the training of handlers, the counts of total coliforms, coagulase positive staphylococci and aerobic mesophilic bacteria presented a statistically significant reduction. A decrease in the count of Escherichia coli in handlers' nostrils was also observed, in addition the high percentage of post-test questions success. Although positive results indicate training efficiency to ensure food sanitary quality, some deficiencies about functional and physical conditions in establishments were still identified, which can hamper the development and implementation of Good Manufacturing Practices and facilitate the contamination of products due to inadequate handling and storage processes.

\section{ACKNOWLEDGEMENTS}

To the Foundation of Research Support of the State of Goiás for financial support and for the granting of scholarships.

Todos os autores declararam não haver qualquer potencial conflito de interesses referente a este artigo.
All authors have stated that there is no potential conflict of interest referring to this article.

\section{REFERENCES}

AOAC. Association of Official Agricultural Chemists. Official methods of analysis. 19 ed. Washington D.C., p. 1141, 2012.

APHA. American Public Health Association. Compendium of methods for the microbiological examination of foods.4th ed. Washington: APHA. p. 676,2001

BRASIL. Ministério da Saúde. Resolução RDC no 216, de 15 de setembro de 2004. Dispõe sobre Regulamento Técnico de Boas Práticas para Serviços de Alimentação, 2004.

COSTA, R.G.; ANDREOLA, K.; MATTIETTO, R. A.; FARIA, L.J.G.; TARANTO, O.P. Effect of operating conditions on the yield and quality of açai (Euterpeoleracea Mart.) powder produced in spouted bed, Brazil. LWT - Food Sci Technol. v. 64, p. 1196$1203,2015$.

EMBRAPA. Brazilian Agricultural Research Corporation (2013). EMBRAPA Eastern Amazon: Acai Production Systems, Belém, PA: EMBRAPA. Available in: $<$ http://sistemasdeproducao.cnptia.embrapa.br/Fontes HTML/Acai/SistemaProducaoAcai_2ed/index.htm>.

FARIA, M.; OLIVEIRA, L.B.D.; COSTA, F.E.C. Determination of the microbiological quality of frozen acai pulp commercialized in the city of Pouso AlegreMG. Braz J Food Nutr. v.23, p. 243-249, 2012.

FIJALKOWSKI, K.; PEITLER, D.; KARAKULSKA, J. Staphylococci isolated from ready-to-eat meat Identification, antibiotic resistance and toxin gene profile, Poland. Int. J. of Food Microbiol. v. 238, p. 113-120, 2016.

FREGONESI, B.M.; YOKOSAWA, C.E.; OKADA, I.A.; MASSAFERA, G.; BRAGA, C.T.M.; PRADO, S.P.T. Frozen açaí pulp: nutritional characteristics, physical chemical, microscopic and evaluation of labeling. Rev Inst Adolfo Lutz. v. 69, p. 387-95, 2010 .

KUNADO, A.P.H.; OFOSU, D. B.; ABOAGYE, E.; TANO-DEBRAH, K. Food safety knowledge, attitudes and self-reported practices of food handlers 
in institutional foodservice in Accra, Ghana. Food Control. 69, 324-330, 2016.

MELLO, A.G.; GAMA, M.P.; MARIN, V.A.; COLARES, L.G.T. Knowledge of food handlers concerning good practices in popular public restaurants in the State of Rio de Janeiro, Brazil. Braz J Food Technol. v. 13, p. 60-68, 2010.

MORRIS, D.; KAVANAGH, S.; CARNEY, K.; MacDomhnaill, B.; CORMICAN, M. CapE (capture, amplify, extract): A rapid method for detection of lowlevel contamination of water with Verocytotoxigenic Escherichiacoli (VTEC), Ireland. Sci of the Total Environ. v. 563, p. 267-272, 2016.

NASROLAHEI, M., MIRSHAFIEE, S., KHOLDI, S.; SALEHIAN, M., NASROLAHEI, M. Bacterial assessment of food handlers in Sari City, Mazandaran Province, north of Iran, Iran. J Infect Public Health, 2016.

PORTINHO, J.P., ZIMMERMANN, L.M., BRUCK ruck, M.R. Beneficial effects of acai, Brazil. International J Nutrol. v.5, p. 15-20, 2012.

REBOUÇAS, , L.T.; SANTIAGO, L. B.; MARTINS, L. S.; MENEZES, A.C.R.; ARAÚJO, M. P.N.; ALMEIDA, R.C.C. Food safety knowledge and practices of food handlers, head chefs and managers in hotels' restaurants of Salvador, Brazil, Brazil. Food Control. p. 1-10, 2016.

SACCOL, A.L.F.; SERAFIM, A.L.; HECKTHEUER, L.H.R.; MEDEIROS, L.B.; SPINELLI, M.G.N., ABREU, E.S.; CHAUD, D.M.A. Hygiene and sanitary conditions in self-service restaurants in São Paulo, Brazil, Brazil.Food Control. v. 33, p.301-305, 2013.

SACCOL, A.L.F.; GIACOMELLI, S.C.; MESQUITA, M.O., CASTRO, A.K.F., SILVA Jr., E.A., HECKTHEUER, L.H.R., 2015. Sanitary legislation governing Food Services in Brazil, Brazil.Food Control. v. 52, p. 27-33, 2015.
SANGADKIT, W.; RATTANABUMRUNG, O.; SUPANIVATIN , P.; THIPAYARAT, A. Practical coliforms and Escherichia coli detection andenumeration for industrial food samples using $\mathrm{v}$. 32, p. $126-133,2012$.

SANI, N.A. ; SIOW, O.N.. Knowledge, attitudes and practices of food handlers on food safety in food service operations at the UniversitiKebangsaan Malaysia, Food Control. 37, 210-217, 2014.

SOARES, K.; GARCIA-DÍEZ, J.; ESTEVES, A.; OLIVEIRA, I., SARAIVA, C.. Evaluation of food safety training on hygienic conditions in food establishments. Food Control. 34, 613-618, 2013.

SOARES, L.S.; ALMEIDA, R.C.C.; CERQUEIRA, E.S., CARVALHO, J.S., NUNES, I.L. Knowledge, attitudes and practices in food safety and the presence of coagulasepositive staphylococci on hands of food handlers in the schools of Camaçari, Brazil. Food Control. v. 27, p. 206-213, 2012.

YAMAGUCHI, K. K. de L., PEREIRA, L. F. R., LAMARÃO, C. V., LIMA, E. S., VEIGA-JUNIOR, V. F. da, Amazon açai: Chemistry and biological activities: A review, Brazil. Food Chem. p.137-151, 2015.

YUYAMA, L.K.O., AGUIAR, J.P.L., FILHO, D.F.S., YUYAM, K., VAREJÃO, M.J., FÁVARO, D.I.T .Physicochemical characterization of acai juice of Euterpeprecatoria Mart. from different amazonian ecosystems. Acta Amaz. V. 41, p. 545-552, 2011.

PERINI, J. A., RODRIGUES, MACHADO, D.E., NASCIUTTI, L. E.. Anticancer potential, molecular mechanisms and toxicity of Euterpe oleracea extract (acai): A systematic review. PLoS One. v.13 (7), p. 16 - 21, 2018. 